\title{
Association between 894G>T Endothelial Nitric Oxide Synthase Gene Polymorphisms and Metabolic Syndrome
}

\begin{abstract}
Metabolic syndrome (MS) is a cluster of cardiovascular risk factors such as hypertension, dyslipidemia, obesity and type II diabetes. Here, we performed a case-control study analyzing the association between $894 G>T$ endothelial nitric oxide synthase gene polymorphism (NOS3) and MS in 616 subjects. Genotype frequencies were $\mathrm{TT}=9.3 \%, \mathrm{GG}=37.2$ and $\mathrm{TG}=53.6 \%$ and the allelic frequencies were $\mathrm{T}=0.36$ and $\mathrm{G}=0.64$. We observed a higher TT genotype frequency in the male MS group than control subjects $(p=0.02)$, independent of other variables. We found an association between hypertension and TT genotype in females. Our data suggests that $894 G>T$ plays a significant role in the mechanistic interaction between metabolic risk such as hypertension and MS, although sex-related differences may exist. (Arq Bras Endocrinol Metab 2008; 52/8:1367-1373)
\end{abstract}

Keywords: NOS3 polymorphism; Nitric oxide synthase; Metabolic syndrome; Cardiovascular risk factors; Metabolic disorder

\section{RESUMO}

Associação entre o Polimorfismo $894 g>T$ do Gene Óxido Nítrico Sintetase Endotelial e Síndrome Metabólica.

A síndrome metabólica (SM) é um agrupamento de fatores de riscos cardiovasculares, tais como hipertensão, dislipidemia, obesidade e diabetes tipo 2. Realizou-se um estudo caso-controle para analisar a associação entre o polimorfismo (894G $>T$ do gene da enzima endotelial oxido nítrico sintetase (NOS3) e a SM em 616 voluntários. As freqüências genotípicas foram: TT = $9,3 \%, \mathrm{GG}=37,2 \%$ e TG $=53,6 \%$, e as freqüências alélicas $\mathrm{T}=0,36$ e $\mathrm{G}=0,64$. Observou-se freqüência mais alta do genótipo TT em homens com SM do que nos controles, independentemente de outros fatores $(p=0,02)$. Também observou-se associação entre hipertensão e o genótipo TT nas mulheres. Os dados do estudo sugerem que o polimorfismo $894 G>T$ pode ter papel significativo na interação entre riscos metabólicos, tais como a hipertensão e a SM, ainda que existam diferenças relacionadas ao sexo. (Arq Bras Endocrinol Metab 2008; 52/8:1367-1373)

Descritores: Polimorfismo da enzima óxido nítrico sintetase (NOS3); Síndrome metabólica; Fatores de risco cardiovasculares; Desordem metabólica

\section{INTRODUCTION}

M etabolic syndrome (MS), a cluster of several metabolic disorders, is increasingly being recognized as a risk factor for cardiovascular disease. The metabolic syndrome risk factors are of metabolic origin and consist of atherogenic dyslipidemia, elevated blood pressure, elevated plasma glucose, a perspectives

\author{
Jacqueline C. Escobar Piccoll \\ Maria Gabriela Valle Gottlieb \\ LUCIANO CASTRO \\ Luiz Carlos Bodanese \\ Euler Roberto Fernandes ManentI \\ MAURICIO REIS BOGO \\ Alessandra Peres \\ MARIA IZABEL U. M. DA ROCHA \\ IVANa Beatrice Mânica da Clruz
}

Laboratório de Biogenômica, Departamento de Morfologia, Centro de Ciências da Saúde e Programa de Pós-Graduação em Bioquímica Toxicológica, Universidade Federal de Santa Maria (JCEP, MGVG, MIUMR, IBMC), Santa Maria, RS, Brasil; Departamento de Ciências Biológicas. Universidade Regional Integrada do Alto Uruguai e das Missões - Campus Santo Ângelo (JCEP), Santo Ângelo, RS, Brasil; Serviço de Cardiologia. Faculdade de Medicina. Pontifícia Universidade Católica do Rio Grande do Sul (MGVG, LCB, ERFM); Faculdade de Educação Física. Pontifícia Universidade Católica do Rio Grande do Sul (LC); Centro de Biologia Genômica e Molecular. Pontifícia Universidade Católica do Rio Grande do Sul (MRB);

Centro Universitário IPA Metodista (AP), Porto Alegre, RS, Brasil

Received in 17/8/2008 Accepted in 16/10/2008 
prothrombotic state and a proinflammatory state $(1,2)$. Therefore, MS is a multifactorial disturbance that potentially includes genetic components of structural and regulatory proteins involved in its pathogenesis (3).

As data from animal models have suggested that nitric oxide synthase (NOS3) null mice show a phenotype that resembles the human metabolic syndrome (hypertension, insulin resistance and hypertriglyceridemia), human studies involving NOS3 gene polymorphism have been initiated (4).

Nitric oxide (NO) produced by endothelium is an ubiquitous molecule responsible for the maintenance of normal endothelial function, acting in vascular homeostasis. This molecule has a protective role by suppressing the abnormal proliferation of vascular smooth muscle cells (VSMCs) following various pathological situations including atherosclerosis $(5,6)$. Additionally, NO facilitates the uptake and metabolism of glucose in skeletal muscle $(7,8)$ In contrast, the oxidative effects of $\mathrm{NO}$, which may occur through functional variation in NO synthase genes, may play a role in insulin resistance and type II diabetes (9).

The NOS3 gene is localized to chromosome $7 \mathrm{q} 35$ 36 (10), and the NOS3 protein synthesizes NO constitutively via a reaction including the conversion of $\mathrm{L}$-arginine to L-citrulline, which involves the transfer of five electrons provided by NADPH $(11,12)$. Several polymorphisms have been identified in the NOS3 gene. Much attention has been focused on putatively functional variants: $-786 T>C($ rs2070744 $), 894 G>T$ (Glu298Asp) (rs1799983) and intron $4 \mathrm{a} / \mathrm{b}$ VNTR (27-bp repeat) (13). A common variation of the NOS3 that leads to an amino acid substitution in the mature protein is the $894 G>T$ or Glu298Asp variant, in which a guanine/thymine substitution at exon 7 leads to a glutamate/aspartate substitution at position 298 (14). This variant has been associated with $\operatorname{CAD}(12,15)$, including an investigation in Brazilian subjects $(16,17)$.

However, there are few studies reporting a possible association between endothelial nitric oxide synthase (NOS3) and MS $(18,19)$. These studies include two surveys performed in a Spanish population that found a positive association between NOS3 polymorphisms and MS $(19,20)$, and an Italian population study that found an association with diabetes mellitus type II and insulin resistance (21). Additionally, a positive association between $894 G>T$ polymorphism and MS has been shown in Chinese and Japanese populations $(18,22)$.
Based on these findings, we performed a study to determine the possible association between MS and $894 G>T$ polymorphism NOS3 in Brazilian subjects.

\section{SUBJECTS AND METHODS}

A case-control study was performed in Rio Grande do Sul (RS), the southernmost state of Brazil. The Ethics Committee of the Pontificia Universidade Católica do Rio Grande do Sul (PUCRS) approved the study protocol. Informed consent was obtained from all individuals whose data were collected prospectively. The study was structured considering the checklist for the reporting and evaluation of gene-disease associations proposed by Little and cols. (23).

We excluded first or second-degree relatives of subjects to avoid genetic frequency bias and included just subjects who reported being Caucasian. Subjects were recruited from the Cardiology Service, São Lucas Hospital (SLH), Brazil and from an epidemiological study of aging and non-transmissible diseases conducted in the metropolitan area of Gravatai, Porto Alegre. Previous genetic studies have been performed in this research project $(24,25)$. Minimal and maximal ages were 35 and 92 years old, respectively. The sample consisted of 231 males (36.6\%) and 401 females $(63.4 \%)$.

Previous clinical history was analyzed including cardiovascular disease. All subjects filled out a questionnaire including demographic characteristics such as age and gender, and were examined for clinical and previous history of cardiovascular risk factors.

MS was diagnosed by the following clinical variables: a) diabetes mellitus, individuals with glucose levels above $110 \mathrm{mg} / \mathrm{dL}$ and those using glucose-lowering drugs; b) hypertension, individuals with systolic blood pressure (SBP) levels $>140 \mathrm{mmHg}$ and/or diastolic blood (DBP) pressure levels $>90 \mathrm{mmHg}$, measured at least on two occasions separated by a month, and using antihypertensive drugs (also including subjects with severe hypertension, i.e., $\mathrm{SBP} \geq 160 \mathrm{mmHg}$ and/or $\mathrm{DBP}$ $\geq 100 \mathrm{mmHg}$ ), and coronary disease, i.e., individuals with a previous diagnosis of acute myocardial infarct (AMI), angina, intermittent claudication or stroke; and c) dyslipidemia, subjects with elevated total cholesterol, LDL-c or TG, as well as those who used drugs to lower cholesterol. Details of these evaluations were given in previous studies by our group (e.g., Schwanke and cols.) (26). 
Biochemical analyses were performed on blood samples collected from subjects after an overnight fasting ( $12 \mathrm{~h}$ or more); snacks and coffee were offered afterward. The following blood tests were performed: glucose, total cholesterol, HDL-c, LDL-c, and triglycerides (TG). Total cholesterol, HDL-c, TG, and glucose were determined by enzymatic colorimetric methods using commercial kits: total cholesterol, Cod-Ana Labtest $\AA$; HDL-c precipitant Labtest ${ }^{\circledR} ;$ TG Gpo-Ana; Glucose PAP Labtest ${ }^{\circledR}$. LDL-c was calculated according to the Friedwald equation: $($ LDL-c) $=(T G)-$ (HDL-c + TG/5) (27).

To perform the molecular analysis, blood samples were drawn from a peripheral vein using disposable Vacutainer tubes containing $0.1 \%$ EDTA (final concentration of $1 \mathrm{mg} / \mathrm{dL}$ ). Afterward, the samples collected were kept at $4^{\circ} \mathrm{C}$ until DNA extraction. Genomic DNA was isolated from peripheral blood leukocytes using the GFX Genomic Blood DNA Purification (Amersham Biosciences Inc., Co.) kit.

The $894 G>T$ polymorphism in exon 7 was detected using the primers 5'-AAGGCAGGAGACAGTGGATG-3' (sense) and 5'-TCCCTTTGGTGCTACGT -3' (antisense) and PCR conditions previously described by Gilerott and cols. (28). The resulting 258-bp fragment was digested with the enzyme Mbol I for $16 \mathrm{~h}$, at $37^{\circ} \mathrm{C}$, producing fragments of 248 bp (G allele) and 158 bp and 90 bp ( $\mathrm{T}$ allele). 786T $>\mathrm{C}$ and $894 G>T$ fragments were separated by electrophoresis in $3 \%$ agarose gels and visualized by ethidium bromide staining.

Statistical analysis was performed using the SPSS/ PC statistical package, version 11.5 (SPSS, Inc., IL). The allelic and genotypic frequencies were tested for Hardy-Weinberg equilibrium. The significance of allele frequency or genotype distribution among controls with different smoking habits was examined by the non-parametric chi-square test, or Fischer's exact test (two-tailed). Multivariate analyses, including gender and age effects, were conducted with multiple logistic regression methods and estimates of conditional relative risk and 95\% confidence intervals (CI). Statistical analyses were performed where all $\mathrm{P}$-values were two-tailed, and $\mathrm{p}<0.05$ was considered statistically significant. To test for intervening factors, we performed a multivariate analysis using the Backward Wald logistic regression.

\section{RESULTS}

The 635 subjects included in this study, 398 SM and 237 controls, had mean ages of $65.4 \pm 8.9$ years and $64.1 \pm 10.3$ years, respectively $(\mathrm{p}=0.111)$. Baseline and clinical characteristics between case-control subjects are presented in Tables 1 and 2 . As expected, these characteristics of MS and control subjects differed for several metabolic traits (Table 1 ) and metabolic risk factors (Table 2). The MS group had higher systolic blood pressure, diastolic blood pressure, glucose, total cholesterol and LDL-C, as well as lower HDL-c values, compared to the control group. Additionally, there was a higher prevalence of diabetes type II, obesity, dyslipidemia, hypertension and smoking addiction in the MS group.

Table 1. Baseline characteristics of metabolic syndrome and control subjects.

\begin{tabular}{|c|c|c|c|}
\hline Variable & Group & Mean \pm SD & $p$ \\
\hline \multirow[t]{2}{*}{ Age (years) } & MS & $65.4 \pm 8.9$ & 0.111 \\
\hline & Control & $64.1 \pm 10.3$ & \\
\hline \multirow[t]{2}{*}{$\mathrm{BMI}(\mathrm{kg} / \mathrm{m} 2)$} & MS & $29.4 \pm 4.4$ & 0.590 \\
\hline & Control & $30.3 \pm 41.5$ & \\
\hline \multirow[t]{2}{*}{$\begin{array}{l}\text { Waist circumference } \\
(\mathrm{cm})\end{array}$} & MS & $94.2 \pm 10.9$ & 0.511 \\
\hline & Control & $93.3 \pm 10.8$ & \\
\hline \multirow[t]{2}{*}{$\begin{array}{l}\text { Systolic blood pressure } \\
(\mathrm{mmHg})\end{array}$} & MS & $144.7 \pm 27.9$ & $\geq 0.001$ \\
\hline & Control & $128.7 \pm 30.2$ & \\
\hline \multirow[t]{2}{*}{$\begin{array}{l}\text { Diastolic blood pressure } \\
(\mathrm{mmHg})\end{array}$} & MS & $80.7 \pm 12.4$ & 0.013 \\
\hline & Control & $76.7 \pm 15.1$ & \\
\hline \multirow[t]{2}{*}{ Glucose (mg/dL) } & MS & $109.0 \pm 60.9$ & $\geq 0.001$ \\
\hline & Control & $54.8 \pm 51.1$ & \\
\hline \multirow[t]{2}{*}{ Total cholesterol (mg/dL) } & MS & $203.8 \pm 65.1$ & $\geq 0.001$ \\
\hline & Control & $99.8 \pm 95.3$ & \\
\hline \multirow[t]{2}{*}{ Triglycerides (mg/dL) } & MS & $165.3 \pm 86.3$ & $\geq 0.001$ \\
\hline & Control & $59.9 \pm 67.6$ & \\
\hline \multirow[t]{2}{*}{ HDL-cholesterol (mg/dL) } & MS & $24.7 \pm 25.3$ & $\geq 0.001$ \\
\hline & Control & $40.3 \pm 14.1$ & \\
\hline \multirow[t]{2}{*}{ LDL-cholesterol (mg/dL) } & MS & $105.6 \pm 70.3$ & $\geq 0.001$ \\
\hline & Control & $49.2 \pm 59.8$ & \\
\hline
\end{tabular}


Table 2. Comparison of cardiovascular risk morbidities between metabolic syndrome and control subjects.

\begin{tabular}{lcccc}
\hline Risk factor & $\begin{array}{c}\text { MS } \\
\mathbf{n ( \% )}\end{array}$ & $\begin{array}{c}\text { Control } \\
\mathbf{n}(\%)\end{array}$ & $\begin{array}{c}\text { OR (95\% } \\
\mathbf{C l})\end{array}$ & p \\
$\begin{array}{l}\text { Diabetes } \\
\text { type II }\end{array}$ & $90(22.6)$ & $14(5.9)$ & $4.6(2.6-8.4)$ & $\geq 0.001$ \\
$\begin{array}{l}\text { Dyslipidemia } \\
253(63.6)\end{array}$ & $20(8.4)$ & $\begin{array}{c}18.9 \\
(11.5-31.2)\end{array}$ & $\geq 0.001$ \\
\hline $\begin{array}{l}\text { Obesity } \\
\text { Hypertension }\end{array}$ & $278(69(49.0)$ & $48(20.3)$ & $3.8(2.6-5.5)$ & $\geq 0.001$ \\
$\begin{array}{l}\text { Smoking } \\
\text { addiction }\end{array}$ & $66(21.3)$ & $26(14.3)$ & $1.6(1.0-2.7)$ & 0.054 \\
\hline
\end{tabular}

In this study, $616(97 \%)$ were genotyped for the $894 G>T$ NOS3 gene polymorphism and included in casecontrol association analysis. Genotype frequencies in the general sample were $\mathrm{TT}=9.3 \%(\mathrm{n}=57), \mathrm{GG}=37.2$ $(\mathrm{n}=229)$ and $\mathrm{TG}=53.6 \%(\mathrm{n}=330)$, and the allelic frequencies were $\mathrm{T}=0.36$ and $\mathrm{G}=0.64$. The genetic frequencies were in Hardy-Weinberg equilibrium $(\mathrm{p}=0.222)$. In the first analysis, where we compared the genotype frequency distribution between case and control subjects, we did not find any significant differences $(\mathrm{p}=0.156)$. However, when we stratified the sample by sex we observed a higher TT genotype frequency in the male SM group than in the control subject grouping in the same genotype category GG and TG $(\mathrm{p}=0.02)$ (Table 3$)$. Therefore, the association between $894 G>T$ NOS3 gene polymorphism showed a recessive condition.
A multivariate analysis was performed to determine if the MS and TT genotype association in males was independent of other intervening variables. We included in the regression equation: age, diabetes type II, hypertension, dyslipidemia, obesity, smoking addiction and previous coronary disease. The significance of MS and $894 G>T$ NOS3 gene polymorphism association was maintained $(\mathrm{p}=0.025)$, therefore, this association was independent of these variables. The MS odds ratio for male TT subjects was 3.4 (1.1-10.1) times higher.

Additional analysis showed a positive association between hypertension and the TT genotype of $894 G>T$ NOS3 gene polymorphism in females $(\mathrm{p}=0.02)$. In the 389 females included in the study, 221 were hypertensive and 168 were normotensive. The frequencies of $894 G>T$ NOS3 gene polymorphism genotypes in hypertensive females were: $\mathrm{TT}=27(12.2 \%), \mathrm{GG}=74$ $(33.5 \%), \mathrm{GT}=120(54.3 \%)$, and in normotensive they were: $\mathrm{TT}=09(5.4 \%), \mathrm{GG}=58(34.5 \%), \mathrm{GT}=101$ $(60.1 \%)$. The multivariate analysis showed that this result was independent of diabetes mellitus type II, dyslipidemia, hypertension, obesity and just MS ( $\mathrm{p}=0.02)$. The hypertension odds ratio for TT subject females was 3.8 (1.2-11.4) times higher.

\section{DISCUSSION}

We report here, for the first time, an association between $894 G>$ T NOS3 gene polymorphism and features of the metabolic syndrome in a Brazilian population living

Table 3. Distribution of allelic, genotypic and genotype combination frequencies in MS versus control subjects.

\begin{tabular}{|c|c|c|c|c|}
\hline Gender & Genotype/Allele & MS & Control & $p$ \\
\hline \multirow[t]{6}{*}{ Male } & $\Pi$ & $14(13.7)$ & $06(4.9)$ & 0.06 \\
\hline & GG & $40(39.2)$ & $55(45.1)$ & \\
\hline & TG & $48(47.1)$ & $61(50.0)$ & \\
\hline & $\Pi \times(G G+T G)$ & $14(13.7) \times 88(86.3)$ & $06(4.9) \times 116(95.1)$ & 0.02 \\
\hline & $\mathrm{T}$ & 0.37 & 0.30 & \\
\hline & $G$ & 0.63 & 0.70 & \\
\hline \multirow[t]{6}{*}{ Female } & TT & $27(9.6)$ & $9(8.3)$ & 0.901 \\
\hline & GG & $94(33.5)$ & $38(35.2)$ & \\
\hline & TG & $160(56.9)$ & $61(56.5)$ & \\
\hline & $\Pi \mathrm{T} \times(\mathrm{GG}+\mathrm{TG})$ & $27(9.6) \times 264(90.4)$ & $9(8.3) \times 99(91.7)$ & 0.698 \\
\hline & $\mathrm{T}$ & 0.38 & 0.37 & \\
\hline & $G$ & 0.62 & 0.63 & \\
\hline
\end{tabular}


in the southernmost region. The effect observed was susceptibility when a recessive model of inheritance was assumed (TT X GT+GG). The biological plausibility of the data described here could be supported by epidemiological and experimental evidence that suggest an association among lipid, blood pressure (29), glucose levels and modulation of NO levels $(5,9,19)$. However, this association was sex-dependent, since it was evident in males, whereas females showed the TT genotype association only with hypertension.

Previous studies have described an association between metabolic syndrome factors and $894 G>T$ gene polymorphism, such as those published by GonzálesSánchez and cols. (19) and Fernandez and cols. (20) However, a great number of the studies have been conducted considering the association between the polymorphism studied here and one or two metabolic risk factors connected to MS, such as hypertension, diabetes type II and dyslipidemia. Several of these studies found a positive association with MS and its diagnostic criteria, suggesting that $894 G>T$ NOS3 gene polymorphism plays a functional role in MS pathogenesis. For example, we can cite a genetic study performed in 1577 Brazilian subjects that showed evidence that $894 G>T$ polymorphism is associated with hypertension risk only in individuals with total cholesterol above $209 \mathrm{mg} / \mathrm{dL}$. The authors suggested that this NOS3 variant has an influence in blood pressure modulation dependent on lipid levels (30).

However, the number of studies suggesting that $894 G>T$ NOS3 polymorphism shows a differential susceptibility that is sex-related is still incipient. A prospective study conducted by Tsao and cols. (31)., investigating the $894 G>T$ NOS3 polymorphism as being predictive of glycemic status in a 5-year follow-up study of 256 Chinese subjects with impaired glucose tolerance, found interesting results. A significant and independent gene effect of this polymorphism on glycemic status at 5 years was demonstrated, with male carriers of $\mathrm{T}(894)$ being more likely to have persistent hyperglycemia compared to GG subjects. Despite the differences in the methodological approaches and in ethnic origin of the samples (Chinese versus Caucasian Brazilian), the results described by Tsao and cols. (33) support the possible association between male susceptibility and the 894G $>$ T NOS3 polymorphism.

Additionally, considering our results where an association was found between TT women and hypertension, a study recently reported by Periaswamy and cols.
(32) found similar results. These authors investigated 438 hypertensive patients and 444 healthy control subjects in an Indian Tamilian homogeneous population. Similar to the results reported here, a positive association was found between $894 G>T$ NOS3 gene polymorphism and hypertension in females. The variant allele $\mathrm{T}$ was more frequent in female hypertensives when compared to male hypertensive cases ( $22 \%$ vs. $16 \%$ ). However, we need to determine if these differences also occur in other populations independent of ethnic origin and the biological causes of it.

A possible major biological cause that could explain the differences found between males and females in the NOS3 susceptibility, and metabolic risks such as MS and hypertension, could be the differences in steroid hormone profile. Clinical trials have revealed that estrogen may promote coronary heart disease, probably by increasing the risk of hypertension, despite earlier studies demonstrating that estrogen provided cardiovascular protection. To understand this phenomenon, new studies conducted in experimental models were performed. Brosnihan and cols. (33) hypothesized that the attenuation of estrogen levels by agonist-induced vasoconstrictor responses through the activation of NOS3, is impaired by hypertension. To test this hypothesis the authors investigated the effects of 17 betaestradiol $(\mathrm{E}(2))$ replacement in normotensive Sprague-Dawley (SD) and (mRen2)27 hypertensive transgenic (TG) rats on contractile responses to three vasoconstrictors, angiotensin II (ANG II), serotonin (5-HT), and phenylephrine (PE), and on the modulatory role of vascular NO in these responses. The study was made in aorta isolated from ovariectomized SD and TG rats treated chronically with $5 \mathrm{mg} \mathrm{E}(2)$ or placebo $(\mathrm{P})$. The results showed that the contribution of NO to the relative refractoriness of the vascular responses was dependent on the nature of the vasoconstrictor and/or the presence of estrogen.

On the other hand, there is substantial evidence from epidemiological studies that estrogen has a beneficial role in pre-menopausal women, preventing vascular inflammation and consequent atherosclerosis. Estrogen exerts its antiinflammatory effects on the vasculature through different mechanisms such as direct antioxidant effect, generation of nitric oxide, prevention of apoptosis in vascular cells and suppression of cytokines and the renin-angiotensin system (34). Although we did not find any influence of age in the results described here, we cannot discard the notion that 
the differences in MS susceptibility related to $894 G>T$ NOS3 polymorphism could be explained by estrogen modulation, considering the reports in the literature.

The results of our study should be interpreted in the context of limitations such as: 1) We performed a casecontrol study, therefore we cannot affirm that after the investigation some control subjects did not have any coronary events. To avoid this bias it is important to reproduce the data considering prospective investigations including comparison between coronary patients without and with MS; 2) The control group used in the current investigation was not submitted to coronary evaluation, but just to volunteers' self-report and general clinical analysis. As coronary examinations are invasive, it is difficult to include truly healthy persons with a complete diagnostic screening for cardiovascular dysfunctions or asymptomatic diseases; 3 ) Additional biochemical markers including $\mathrm{NO}$ and steroids levels were not determined. As we designed the study we did not know about the possible differential response between sexes, we believe that complementary investigations focusing the differential biomarkers associated with MS and $894 G>T$ NOS3 polymorphism need to be performed; 4) The investigation was made only in Caucasian subjects, and therefore, the data cannot be considered as representative of the Brazilian population. The data obtained here need to be reproduced in other Brazilian geographical regions to confirm that ethnic origin and miscegenation are not intervening variables.

Our data support previous notions that NO metabolism plays a significant role in the mechanistic interaction between metabolic risk such as hypertension and MS, although there can be sex-related differences. Therefore, we believe that additional studies exploring the possible role of gene-gene, gene-environment and physiological variables related to sex physiology are needed and that our observations may have relevance in epidemiological and/or clinical implications.

Acknowledgments: The study was supported by grants and fellowships from Conselho Nacional de Desenvolvimento Cientifico e Tecnológico (CNPq, n ${ }^{\circ}$ 471233/2007-2, n 311231/2006-3) and CAPES (Coordenação de Aperfeiçoamento de Pessoal de Nivel Superior, $\left.n^{\circ} 166 / 08\right)$. No potential conflict of interest relevant to this article was reported.

\section{REFERENCES}

1. Expert Panel on Detection, Evaluation, and Treatment of High Blood Cholesterol in Adults. Executive summary of the third report of the National Cholesterol Education Program (NCEP) Expert Panel on Detection, Evaluation, and Treatment of High Blood Cholesterol in Adults (Adult Treatment Panel III). JAMA. 2001;285:2486-97.

2. National Cholesterol Education Program (NCEP) Expert Panel on Detection, Evaluation, and Treatment of High Blood Cholesterol in Adults (Adult Treatment Panel III). Third report of the National Cholesterol Education Program (NCEP) Expert Panel on Detection, Evaluation, and Treatment of High Blood Cholesterol in Adults (Adult Treatment Panel III) final report. Circulation. 2002;106:3143-421.

3. Alberti KGMM, Zimmet P, Shaw J, for the IDF Epidemiology Task Force Consensus Group. The metabolic syndrome - a new worldwide definition. Lancet. 2005;366:1059-62.

4. Cook S, Hugli O, Egli M, Vollenweider P, Burcelin R, Nicod P, et al. Clustering of cardiovascular risk factors mimicking the human metabolic syndrome $\mathrm{X}$ in NOS3 null mice. Swiss Med Wkly. 2003; 133(25-26):360-3.

5. Napoli C, de Nigris F, Williams-Ignarro S, Pignalosa O, Sica V, Ignarro LJ. Nitric oxide and atherosclerosis: An update. Nitric Oxide 2006; 15:265-79.

6. Naseem KM. The role of nitric oxide in cardiovascular disease. Mol Asp Med. 2005; 26:33-65.

7. Balon TW, Nadler JL. Evidence that nitric oxide increases glucose transport in skeletal muscle. J Appl Physiol. 1997;82 (1):359-63.

8. Higaki A, Ninomiya H, Saji M, Maki H, Koike T, Ohno K. Protective effect of neurotropin against lipopolysaccharide-induced hypotension and lethality linked to suppression of inducible nitric oxide synthase induction. Jpn J Pharmacol. 2001;86 (3):329-35.

9. Pieper GM. Enhanced, unaltered and impaired nitric oxidemediated endothelium-dependent relaxation in experimental diabetes mellitus: importance of disease duration. Diabetol. 1999;42(2):204-13.

10. Marsden PA, Heng HH, Scherer SW, Stewart RJ, Hall AV, Shi $\mathrm{XM}$, et al. Structure and chromosomal localization of the human constitutive endothelial nitric oxide synthase gene. J Biol Chem. 1993; 268:17478-88.

11. Mayer B, Hemmens B. Biosynthesis and action of nitric oxide in mammalian cells. Trends Biochem Sci 1997;22:477-81.

12. Moncada S, Higgs A. The L-arginine-nitric oxide pathway. N Engl J Med. 1993;329:2002-12.

13. Stuehr DJ. Structure-function aspects in the nitric oxide synthases. Annu Rev Pharmacol Toxicol. 1997;37:339-59.

14. Hingorani $A D$, Liang $C F$, Fatibene J, Lyon A, Monteith S, Parsons $A$, et al. A common variant of the endothelial nitric pxide synthase $\left(\mathrm{Glu}^{298} \rightarrow \mathrm{Asp}\right)$ is a major risk factor for coronary artery disease in the UK. Circulation. 1999;100:1515-20.

15. Lapu-Bula R, Quarshie A, Lyn D, Oduwole A, Pack C, Morgan $\mathrm{J}$, et al. The 894T allele of endothelial nitric oxide synthase gene is related to left ventricular mass in African Americans with high-normal blood pressure. J Natl Med Assoc. 2005;97 (2): 197-205.

16. Iturry-Yamamoto GR, Moriguchi EH, Zago AC, Alho CS, Zago AJ. Association of the $894 \mathrm{G}>T$ polymorphism of the endothelial constitutive nitric oxide synthase gene with unstable angina. Braz J Med Biol Res. 2007;40(4):475-83.

17. Piccoli JCE. Estudo associativo entre três polimorfismos (-786T>C, 894G $>T$ e VNTR INTRON $4 \mathrm{a} / \mathrm{b})$ no gene que sintetiza para óxido nítrico sintase endotelial e síndrome coronariana aguda. 2007. [database on the Internet]. Available from:: http:// tede.pucrs.br/tde_busca/arquivo.php?codArquivo $=836$. 
18. Hsieh MC, Hsiao JY, Tien KJ, Chang SJ, Lin PC, Hsu SC, et al. The association of endothelial nitric oxide synthase $894 G>T$ polymorphism with $\mathrm{C}$-reactive protein level and metabolic syndrome in a Chinese study group. Metabolism. 2008;57(8): 1125-29.

19. González-Sánchez JL, Martínez-Larrad MT, Sáez ME, Zabena C, Martínez-Calatrava MJ, Serrano-Ríos M. Endothelial nitric oxide synthase haplotypes are associated with features of metabolic syndrome. Clin Chem. 2007;53(1):91-7.

20. Fernandez ML, Ruiz R, Gonzalez MA, Ramirez-Lorca R, Couto C, Ramos A, et al. Association of NOS3 gene with metabolic syndrome in hypertensive patients. Thromb Haemost. 2004;92 (2):413-8.

21. Monti LD, Barlassina C, Citterio L, Galluccio E, Berzuini C, Setola $E$, et al. Endothelial nitric oxide synthase polymorphisms are associated with type 2 diabetes and the insulin resistance syndrome. Diabetes. 2003;52(5):1270-5.

22. Imamura A, Takahashi R, Murakami R, Kataoka H, Cheng XW, Numaguchi $Y$, et al. The effects of endothelial nitric oxide synthase gene polymorphisms on endothelial function and metabolic risk factors in healthy subjects: the significance of plasma adiponectin levels. Eur J Endocrinol. 2008;158(2):189-95.

23. Little J, Bradley L, Bray MS, Clyne M, Dorman J, Ellsworth DL, et al. Reporting appraising and integrating data on genotype prevalence and gene-disease associations. Am J Epidemiol. 2002;156:300-10.

24. Prado-Lima PA, Chatkin JM, Taufer M, Oliveira G, Silveira E, Neto CA, et al. Polymorphism of 5HT2A serotonin receptor gene is implicated in smoking addiction. Am J Med Genet B Neuropsychiatr Genet. 2004;128B (1):90-3.

25. Taufer M, Peres A, de Andrade VM, de Oliveira G, Sá G, do Canto ME, et al. Is the Val16Ala manganese superoxide dismutase polymorphism associated with the aging process? J Gerontol A Biol Sci Med Sci. 2005;60(4):432-8.

26. Gottlieb MG, Schwanke $C H$, Santos $A F$, Jobim PF, Müssel DP, da Cruz IB. Association among oxidized LDL levels, MnSOD, apolipoprotein E polymorphisms, and cardiovascular risk factors in a south Brazilian region population. Genet Mol Res. 2005;4(4):691-703.

27. Prado-Lima PS, Cruz IB, Schwanke $\mathrm{CH}$, Netto CA, Licinio J. Human food preferences are associated with a 5-HT(2A) serotonergic receptor polymorphism. Mol Psychiatry. 2006;11(10): 889-91.

28. Schwanke $\mathrm{CH}$, da Cruz IB, Leal NF, Scheibe R, Moriguchi $Y$, Moriguchi EH. Analysis of the association between apolipo- protein E polymorphism and cardiovascular risk factors in an elderly population with longevity. Arq Bras Cardiol. 2002;78 (6):561-79.

29. Tonks DB. Quality control in clinical laboratories. Warner-Chilcott Laboratories: Scarborough; 1972.

30. Gillerot G, Debaix H, Devuyst O. Genotyping: a new application for the spent dialysate in peritoneal dialysis. Nephr Dial Transpl. 2004;19:1298-301.

31. Nedeljkovic ZS, Gokce N, Loscalzo J. Mechanisms of oxidative stress and vascular dysfunction. Postgrad Med J. 2003; 79:195-200.

32. Pereira AC, Sposito AC, Mota GF, Cunha RS, Herkenhoff FL, Mill JG, et al. Endothelial nitric oxide synthase gene variant modulates the relationship between serum cholesterol levels and blood pressure in the general population: New evidence for a direct effect of lipids in arterial blood pressure. Atheroscl. 2006;184:193-200.

33. Tso AW, Tan KC, Wat NM, Janus ED, Lam TH, S L Lam K. Endothelial nitric oxide synthase $894 G>T$ (Glu298Asp) polymorphism was predictive of glycemic status in a 5-year prospective study of Chinese subjects with impaired glucose tolerance. Metabolism. 2006;55(9):1155-8.

34. Periaswamy R, Gurusamy U, Shewade DG, Cherian A, Swaminathan RP, Dutta TK, et al. Gender specific association of endothelial nitric oxide synthase gene (Glu298Asp) polymorphism with essential hypertension in a south Indian population. Clin Chim Acta. 2008;395(1-2):134-6.

35. Brosnihan KB, Li P, Figueroa JP, Ganten D, Ferrario CM. Estrogen, nitric oxide, and hypertension differentially modulate agonist-induced contractile responses in female transgenic (mRen2)27 hypertensive rats. Am J Physiol Heart Circ Physiol. 2008;294(5):H1995-2001.

36. Chakrabarti S, Lekontseva O, Davidge ST. Estrogen is a modulator of vascular inflammation. IUBMB Life. 2008;60(6):376-82.

\section{Correspondence to:}

Ivana Beatrice Mânica da Cruz

Av Congonhas 153/303, Camobi

90900-120 Santa Maria, RS.

E-mail address: ibmcruz@hotmail.com 